\title{
CONCEPT OF SOPHA (INFLAMMATION): A CRITICAL STUDY
}

\author{
Ashok Kumar Panda ${ }^{* 1}$, Rabinarayan Tripathy ${ }^{2}$ \\ ${ }^{* 1}$ Research Officer, Central Ayurveda Institute for Hepatobiliary Disorders, CCRAS, Ministry of \\ AYUSH, Govt. of India, Bhubaneswar, India \\ 2 Professors, Amrita School of Ayurveda, America Viswavidyapeetham, Amritapuri Campus, \\ Kollam; 690525, India
}

DOI: https://doi.org/10.29121/granthaalayah.v8.i8.2020.692

Article Type: Research Article

Article Citation: Ashok Kumar Panda, and Rabinarayan Tripathy. (2020). CONCEPT OF SOPHA (INFLAMMATION): A CRITICAL STUDY. International Journal of Research -GRANTHAALAYAH, 8(8), 15-23.

https://doi.org/10.29121/granthaa layah.v8.i8.2020.692

Received Date: 13 July 2020

Accepted Date: 18 August 2020

Keywords:

Antah Sopha

Bahir Sopha

Inflammation

Sotha

Soyathu

Vrana Sopha
ABSTRACT

Back ground- Inflammation has a decisive role in pathological classification of diseases in modern medicine and well-known phenomenon of infectious diseases and Non communicable disorders (NCD) also. Ayurveda emphasised the doshic involvement in pathophysiology of diseases process and the phenomenon of Sopha is undetermined in diagnosis and treatment.

Objective- A literature survey from Ayurveda classical texts was undertaken to understand the role of Sopha in disease process.

Methods- The enumerations of Sopha in Bruhatrayee, Madhav nidana \& Bhela Samhita are critically studied to find out its etiology, types, pathogenesis and line of treatment.

Enumeration- Sopha is very fundamental to understand the disease process in Ayurveda. The normal snigdha-sheet- agneya character of Srotas get disturbed by the Vidahi \& Abhisandhya dravyas, as a result there is a disturbed in the transport mechanism of the affected Srotas. Sopha can be a symptom of any disease and/or an independent disease and may be a complication of other diseases. Sopha can be classified as Antah Sopha \& Bahir Sopha.

Discussion- The concept of sopha was discussed in terms of pathology and treatment of modern science.

Conclusion- Sopha is linked with wide spectrum of Infectious as well as Non communicable disorders (NCD). This study also found out a range of therapies for Sopha driven diseases. It can be recommended to include this concept of Sopha in Ayurveda undergraduate and post graduate curriculum.

\section{INTRODUCTION}

Sopha (Inflammation) is a complex biological response of vascular tissues to harmful stimuli, such as pathogens, damaged cells, or irritants. The classical signs of acute inflammation are pain (dolor), heat (calor), redness (rubor), swelling (tumor), and loss of function (functio laesa). Inflammation is a protective attempt by vascular reaction and cellular reaction to remove the injurious stimuli and to initiate the healing process [1]. It also linked with wide spectrum of Infectious as well as Non communicable disorders (NCD) like- allergies, cardiovascular dysfunctions, metabolic syndrome, cancer, and autoimmune diseases imposing a huge economic burden on individuals and

(C) 2020 The Author(s). This is an open access article distributed under the terms of the Creative Commons Attribution License, which permits unrestricted use, distribution, and reproduction in any medium, provided the original author and source are credited. 
consequently on the society [2]. Prolonged inflammation causes tissue destruction, tissue remodeling (e.g., extensive fibrosis) that may eventually cause irreversible tissue dysfunction, scaring and reshaping the architecture of tissue as well as gene expression that sustain tumour genesis [3]. There is an imbalance between Inflammation and antiinflammatory pathway due to alteration in immune system function which promotes chronic inflammation. Changes in the tissue micro-environment, such as the accumulation of cell debris, and systemic changes in metabolic and hormonal signals, also likely contribute to the development of chronic inflammation [4]. In vivo and/or in vitro studies indicate that anti-IBD effects of natural products occur by inhibition of the expression of proinflammatory cytokines (for example, tumour necrosis factor- $\alpha$ (TNF- $\alpha$ ), intercellular adhesion molecule expression and pro-inflammatory mediators (such as inducible nitric oxide synthase (iNOS) and cyclooxygenase 2 (COX2), master transcription factors (such as nuclear factor- $\kappa \mathrm{B}(\mathrm{NF}-\kappa \mathrm{B})$ ), reactive oxygen species (ROS) and by improving the antioxidant activity [5], [6].

There is a wide verity of disease described in Ayurveda where the pathogenesis progress through derangement of three body-control systems, viz., doshic imbalance or neuro-humoral derangement, metabolic derangement (agnimandya and ama production) \& nutritional derangement. The permutation and combination of these threecontrol mechanism, its representation in the form of clinical feature is termed as disease. In contrary it can also be argued that representation of body's response to any deranged control is illness. In this way body initially reacts with a defensive manner. Modern medical literature classifies the disease either Inflammatory, neoplastic or degenerative. However, either pathological process undergoes tissue reaction. According to ayurvedic paradigm, even the nomenclature, classification and enumeration of the disease are done on the basis of clinical representation and relatively higher involvement of vitiated dosha. The Pathological background has been ignored during naming the disease but the same is again highlighted during treatment principle. It is also found that sothaghna (antiinflammatory) medications are enumerated in classical texts. In Ancient literature swelling or inflammation is explained in different terminology, varna-sopha, abhighataja-sopha, Sotha or Swayathu. Vranasopha is Inflammatory Swelling, Abhighataja Sopha - Traumatic Swelling, Sotha/ Swayathu is the swelling as a pathological process. Although vrana sopha, sotha, vidradhi, Arbuda, granthi, Apchi, Kilaka, meda roga, hrud roga, Yakruit-dalludaha, Plihodara, jalodara and so on are different disease entity, even those have their inflammatory back ground.

\section{OBJECTIVE}

To understand the role of Sopha in the enumeration of disease, pathological process and deciding the treatment

\section{METHODS}

A literature survey from Ayurveda classical texts were undertaken to enumerate sopha in Bruhatrayee, Madhav nidana \& Bhela Samhita are critically studied and an attempt was made to find out its aetiology, types, pathogenesis and line of treatment in light of recent publications.

\section{ENUMERATION}

The concept of sopha is very fundamental to understand the disease process in Ayurveda. We know that the basic living units of our body are dosa, dhatu \& mala. Charak described the body as Srotomayam. It means that the living body exists due to the microcirculation for the transportation of dosa \& asthayi dhatu and removal of the mala. Among the tridosa- Kapha \& Pitta, all of the dhatus except asthi dhatu and all mala contain considerable amount of drava (fluid). These fluids have the constant motion throughout the body due to the biological motive force i.e.Vata. Vata also regulates the vaso-motion by opening and closing the cell membrane receptors, meta-arterioles and precapillary spinters. It also maintains the colloid osmotic and hydrostatic pressure. The maintenance of a relative constant volume and a stable composition of dhatu are essential for Swastha (health). Some of the most common problem in clinical medicine arises because of the abnormalities in the control system that maintains the constancy \& consistency of dhatu. Therefore, we called "dhatusamya kriya chokta tantra sasya proyojanam" i.e. the objectives of our text is to maintain the eqilibrium of dhatu. 
In certain circumstances the normal snigdha-sheet- agneya character of Srotas get disturbed by the Vidahi \& Abhisandhya dravyas, as a result there is a disturbances in the transport mechanism of the affected Srotas. So this retention or accumulation of the fluid is termed as Sopha. With reference to the classical knowledge Sopha is a condition which is characterised by the features like Grathita (hard swelling), Sama /Vishama (regular or irregular), Twak mamsa sthayi (located superficially), sharira ekadeshasthit(localised lesion).

Table 1: Classic Signs of Inflammation with its doshic involvement

\begin{tabular}{|c|c|c|c|}
\hline Feature & $\begin{array}{c}\text { Dosha } \\
\text { Involvement }\end{array}$ & Clinicalpresentation & Pathophysiology \\
\cline { 1 - 1 } Rubor & Pitta vitiation & erythema due to capillary dilation & $\begin{array}{c}\text { Increased blood flow, Elevated cellular } \\
\text { metabolism }\end{array}$ \\
\cline { 1 - 2 } Calor & & warmth due to increased blood flow & Vasodilatation, Increased Blood Flow \\
\hline Tumor & $\begin{array}{c}\text { Kapha } \\
\text { Vitiation }\end{array}$ & edema & $\begin{array}{c}\text { Vasodilatation, Extravasation of fluid } \\
\text { (Permiability) }\end{array}$ \\
\cline { 1 - 1 } Dolor & Vata Vitiation & $\begin{array}{c}\text { pain due to local pressure and } \\
\text { stimulation of nerve endings }\end{array}$ & $\begin{array}{c}\text { Release of Soluble Mediators, Cellular influx } \\
\text { (Chemotaxis), Elevated Cellular Metabolism }\end{array}$ \\
$\begin{array}{c}\text { Functio } \\
\text { laesa }\end{array}$ & & alteration in function & \\
\hline
\end{tabular}

Charaka narrated that all the diseases can be interpreted as the manifestation of Sopha in different structure of the body. Susruta explained the Vrana as the outcome of Vrana-Sopha. Vidradhi \& Arbuda are the subsequent stages of Sopha. As per the explanation of Ayurvedic dogmas various intrinsic and extrinsic etiological factors, cause the aggravation of all the three dosha, which in turn vitiate the rakta dosha that either travel through the vessels (rasayani or srotos), or may localise in the area of trauma, where ever there is low immunity or relatively weakened structure (kha vaigunya) resulting in the causation of a shopha. In sopha, (Table no 1 )pain is because of vitiated vata, burning sensation and suppuration by vitiated pitta, swelling and discharge by vitiated kapha and the area appears red because of the involvement of vitiated pitta/rakta. Thus vitiated

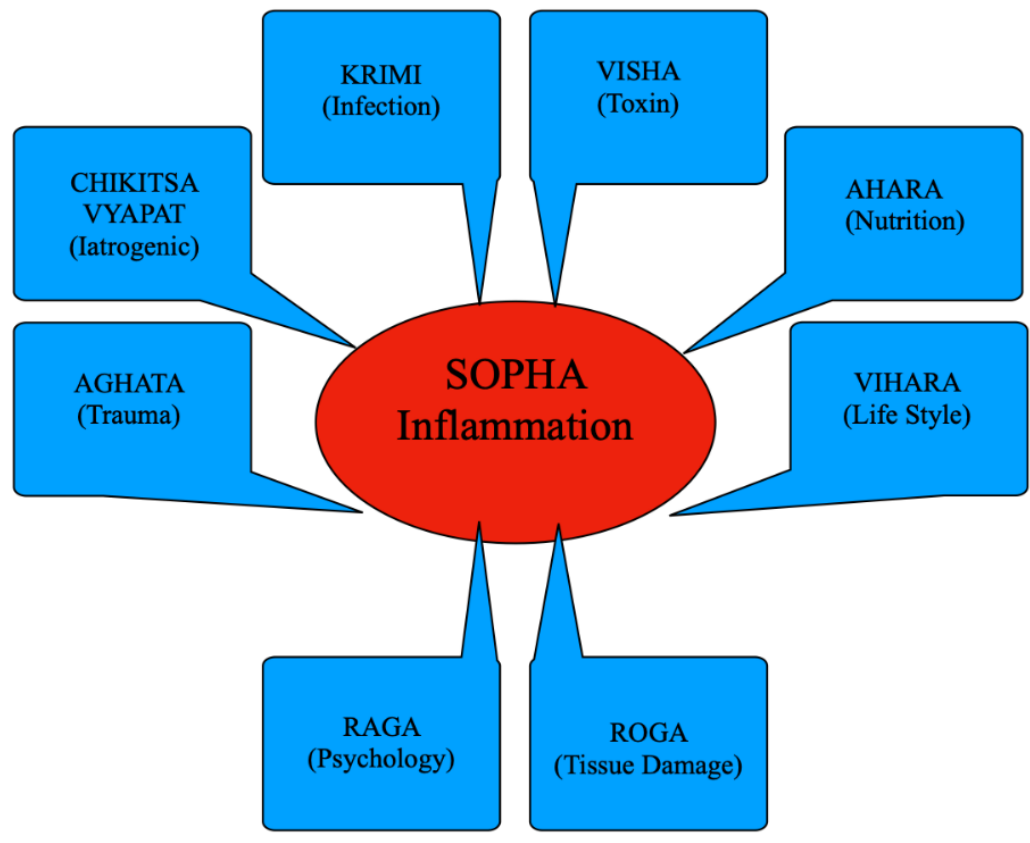

Figure 1: Sopha nidan 
Rakta along with vitiated dosha, play an important role in ensuring paka. of sopha. It is also interesting to note that Susruta has explained Tridosa in the chapter of "Vrana prasna Adhyaya", which implies involvement of tridosa in the formation of Sophia intern as vrana. According to Ayurveda, Sopha can be a symptom of any disease, an independent disease and a complication of other diseases. Srotas or micro channel is the important factor for the pathogenesis of Sopha. Food and regimen that are identical with the morbid dosa and antagonist to the corresponding dhatu can vitiate the micro channels. Although Charaka has not explained the Sopha in Nidana sthana but he narrated the types, sign symptom pathogenesis and treatment in trisothiya \& Svayathu Chikitsa respectively[7], [8].

Table 2: Nidana of Sopha

\begin{tabular}{|c|c|}
\hline SOPHA & NIDANA (Causative Factor) \\
\hline $\begin{array}{c}\text { Agantuja } \\
\text { Sopha }\end{array}$ & Chedana, bhedha, prahara,vadha, bandana, peedana, hima \& agni sparsha, visha, krimi \\
etc.
\end{tabular}

The Sanskrit meaning of Sopha is gati vrudhi (excessive movement of fluid). The other synonyms are Svayathu \& Sotha, that varies according to the severity. The mild inflammatory reaction can be regarded as Sopha, moderate edematous swelling is Svayathu and severe edematous manifestation is Sotha. Charaka mostly used the term Sotha \& Svayathu whereas Susruta \& Bhela mostly used the term Sopha. In simple term it can refer as Swelling. Vata is the prime dosa in the manifestation of Sopha. So, the origin place of Sopha is Pakyasaya.

From the critical study of Bruhatrayee, Madhav nidana \& Bhela Samhita it is well observed that Sopha can be manifested internally without visible oedema as like Jvara. It can also affect the internal organs as like- Plihavridhi, yakriut Vridhi, Kasa, Swasa, Hrud roga etc, which can be better understood if we consider the accumulation of the fluid in the potential spaces as in jalodara.

Table 3: Sopha classification

\begin{tabular}{|c|c|}
\hline Sopha & Types \\
\hline Ekavidha & Utsedha \\
\hline \multirow[t]{4}{*}{ Dvividha } & b) Chirakari (Chronic) \\
\hline & a) Nija b) Agantuja \\
\hline & a) Bahya b) Abhyantar \\
\hline & a) Ekanga b) Sarvanga \\
\hline
\end{tabular}

All ofthe Asta Vrana vastu (tvak, mamsa, sira, snayu, asthi, sandhi, kostha \& marma) are involved in the manifestation of Sopha [9]. Sopha can also be expressed externally as in Sotha, Slipada, Pidaka, Rohini, galaganda, Kusta,Visarpa, Romantika, Masurika ,Bhagandara etc. The internal Sopha can be modified into external Sopha and vice versa. Various Acharyas in their classics classified Sopha on the basic of either etiology or symptom or affected body part, but as per this study it can be classified on the basic of darsasna parikshya (Visibility) of observer /patient into Antah Sopha \& Bahir Sopha. Vagbhatta classified Sopha into nine types in which he subdivided the Agantuga Sopha of Charak into Abhighataja \& Visaja. Vahir Sopha (External swelling) is mostly found in our clinical practices. It can be further divided into generalized and localized. The disease (Roga) and Complication of treatment (chikitsa vyapat) are the etiology of both types of Sopha. The psychological factor like- Raga (attachment/affinity) can also produce Internal swelling as for example- More affinity towards sneha leads swaulya (obesity) which is a inflammatory disorder (Table no-2, 3, 4 \& fig no 1) 
Table 4: Aetiology of two different Sopha

\begin{tabular}{|c|c|}
\hline $\begin{array}{c}\text { Etiology of Bahir Sopha } \\
\text { (External Inflammation }\end{array}$ & $\begin{array}{c}\text { Etiology of Antah Sopha } \\
\text { (Internal inflammation) }\end{array}$ \\
\hline $\begin{array}{c}\text { Ahara- Amla \& Katu rasa, Kshyara, Ushna,rukshya,suska,guru, tikna, } \\
\text { vidahi guna Paryusita(stale) ahara,etc. }\end{array}$ & $\begin{array}{c}\text { Mandagni- Depression of the metabolic } \\
\text { system of the body. }\end{array}$ \\
\hline Vihara- Nidra, Maithuna (sex), Achesta (lack of exercise) & $\begin{array}{c}\text { Ksheena Dhatu-Lack of adequate } \\
\text { nutrition to the dhatu }\end{array}$ \\
\hline $\begin{array}{c}\text { Visa (poison)- Gara \& dusi Visa, Keeta visa, Sarpa visa, Krimi etc } \\
\text { Bravya- Shaka, Dadhi, Pistanna, Matsya,, Soma rasayana,Suskamamsa, } \\
\text { Bhallataka, Kapikacchu, etc }\end{array}$ & $\begin{array}{c}\text { Dhatusrava - Drainage of dhatu as in } \\
\text { Prameha, Atisara }\end{array}$ \\
\hline $\begin{array}{c}\text { Aghata (external injury) like- Vyadha ,Damsa, excessive pressure \& } \\
\text { Fracture. }\end{array}$ & $\begin{array}{c}\text { Ragannels) - Lostam (Clot) } \\
\text { Extra affinity towards object i.e. }\end{array}$ \\
\hline $\begin{array}{c}\text { Chikitsa Vyapat (Complications of treatment)- VastiVyapat,Sneha } \\
\text { vyapat } \quad \text { Bandhna vyapat( Bandage), etc }\end{array}$ & $\begin{array}{c}\text { Chikitsa Vyapat (Complications of } \\
\text { treatment)- Like VastiVyapat, dosa } \\
\text { utklesa }\end{array}$ \\
\hline $\begin{array}{c}\text { Samsparsa (Contact)- Bhallataka, Kapikacchu, Samudra (ocean), etc. } \\
\text { Roga (diseases) - Arsa, Bhagandara,Kusta, Udara, Pandu, Chardi,Rakta } \\
\text { pradara, Garbha(Pregnancy), Ama garbha pata (Abortion) }\end{array}$ & $\begin{array}{c}\text { Vegadharana- Suppression of natural } \\
\text { urges }\end{array}$ \\
\hline $\begin{array}{c}\text { Roga (diseases) like- atisara, grahani, } \\
\text { swasa, jvara, sosa etc }\end{array}$ \\
\hline
\end{tabular}

As per the pathogenesis of Sopha, Kapha, Rakta \& Pitta enter the external as well as internal vessels and afflict the Vayu of that particular area resulting the blockage of micro- circulation. Bhela opine that Meda Kaphanubandha (fat mixed with kapha) can block the channel. Siranam ayama (dilatation of the vessels) that may increase the capillary filtration and capillary permeability causes the abnormal leakage of the fluid to the interstitial spaces across the capillary. The sign symptoms are varies according to the dosic involvement [10], [11], [12], [13].

Table 5: Pathologic progress as per Satkriyakala

\begin{tabular}{|c|c|}
\hline Pathological Stages & Pathological Event \\
\hline $\begin{array}{l}\text { SANCHAYA - Stage of } \\
\text { Accumulation }\end{array}$ & Mithyahara vihara or Trauma, Accumulation of dosha at normal sites \\
\hline PRAKOPA - Stage of Provocation & $\begin{array}{c}\text { Dosha further aggravates, Vata active and Pitta \& Kapha passive, Vilayana } \\
\text { rupa vriddi, Unmarga gamita }\end{array}$ \\
\hline PRASARA - Stage of Propagation & Vitiated dosha migrate their own places, Circulate throughout the body \\
\hline $\begin{array}{l}\text { STHANA SAMSHRAYA - Stage of } \\
\text { Localization }\end{array}$ & $\begin{array}{c}\text { Twak, Mamsa sira adi Dhatu dusti, Dosha lodged in area of lesser resistance, } \\
\text { Menifestation of prodromal symptom }\end{array}$ \\
\hline VYAKTI - Stage of Manifestation & $\begin{array}{l}\text { Appearance of Clinical feature of Sopha in relation to the particular organ } \\
\text { (Ama, Pachyamana \& Pakwavastha) }\end{array}$ \\
\hline BHEDA - Stage of Complication & Communicated to adjacent organs, Upadrava \\
\hline
\end{tabular}

The line of treatment totally depends on the nature of dosa, involvement of ama, consistency of dhatu, bala, kala and Srotas condition. More emphasis had given to the condition of Srotas (Table no 5 \& fig no 2) by our Acharys. 
Charaka put forth the Svayathu hara gana nothing but the Dosamoola in his fifty pharmacological basis of classification and Haritaki is the drug of choice in many instances. Therefore Dsamula Haritaki/ Kansa Haritaki is the drug of choice in many diseases. Swasa and Mutraghata will be applicable for the treatment of Prana, Udaka \& Anna vaha Srotas and Mutra, Purisa\& Sweda vaha Srotas respectively. It means that Sodhana is necessary for conditioning the Srotas in Sopha chikitsa that's why

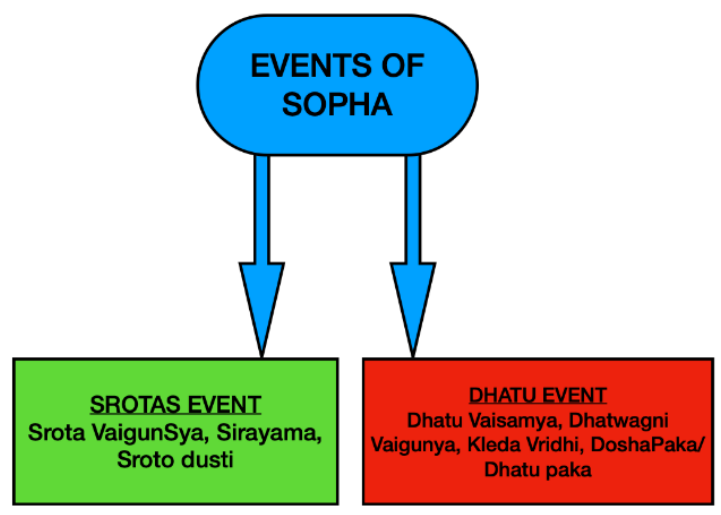

Figure 2: Sopha Events

Charaka advice to advocate Virechana when Svayathu in the lower part of body, Vamana when Svayathu in the upper part of body and and Sira-virechana when Svayathu in the Shiras and Kamsaharitaki, Potalamuladi kasaya \& Punnavarista narrated in the Svayathu chikitsa. But when involvement of ama is suspected, then Langhana, Pachana \& Sodhana should be advised. Bhela advice to advocate Santarpana \& Sodhana in Sopha Chikitsa and Kalyanaka, Mohatiktaka \& Panchagabya grita is advised for the santarpana purpose. Charaka also advised that if excessive intake ruksya food and drinks cause Svayathu then oleation therapy should give and if Svayathu is caused by excessive intake and administration of Sneha then ruksyana therapy should be given. If Svayathu is caused by the simultaneous aggravation of Pitta and Vayu then Tiktaka grita should be administrated. If Svayathu is caused by the aggravation of Kapha then Kshra, Katu \& Ushna dravya should be administrated. Therefore, there is no any specific treatment modality for Antah Sopha \& Bahir Sopha, the etiological factors are important for the administration of the correct treatment. Physician should understand the correct srotas involvement for Antah Sopha \& Bahir Sopha.

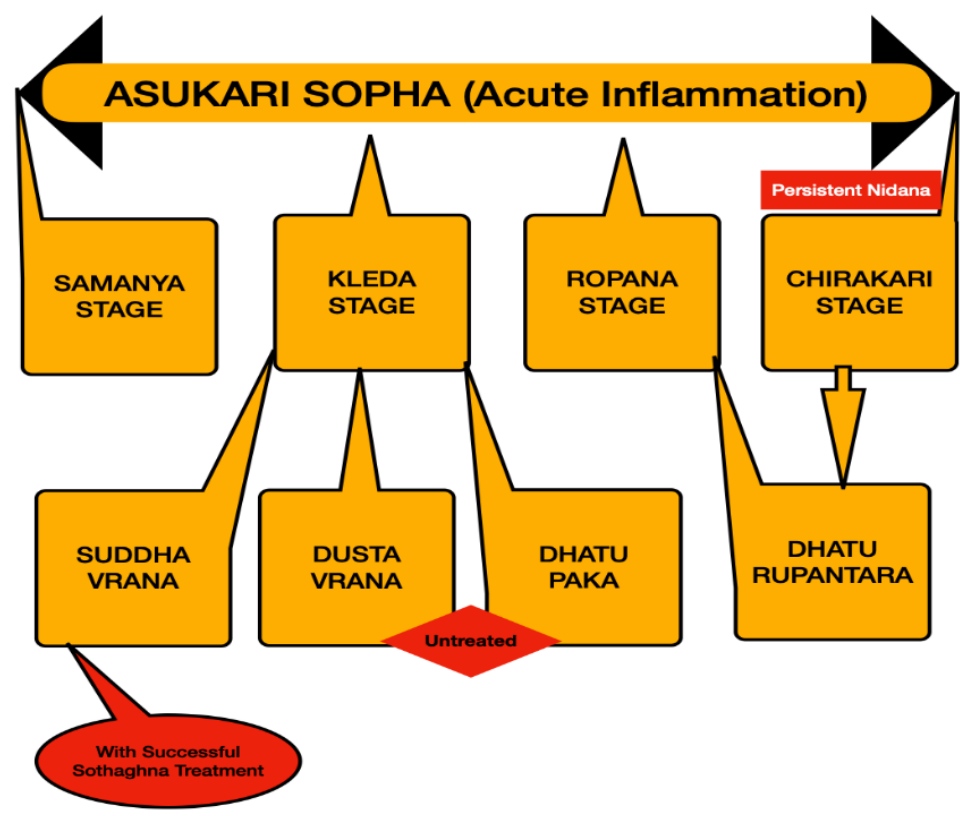

Figure 3: Sequels of Asukari Sopha 


\section{DISCUSSION}

The aetiology, types, pathogenesis and line of treatment of sopha are scatter in different classical text of Ayurveda. The Srotomayam can be explained as water-filled pores with diameters of about $0.8 \mathrm{~nm}$, as well as proteinlined pores, called channels in cell membrane, which allow passage of specific molecules [15].

Table 6: Treatment Principle of Sopha

\begin{tabular}{|c|c|}
\hline Chikitsa Sutra & Treatment Principles \\
\hline Nidana Parivarjana, & \\
Dosha,Rutu vipareeta chikitsa & Depending on the adhikata of doshas samsargaja \& sannipataj are treated \\
\cline { 2 - 2 } & Ekadeshashrita shotha depending on area involved plan the treatment \\
\cline { 2 - 2 } & In Agantuja shotha - Vatarakta \& visarpavat treatment \\
\cline { 2 - 2 } & vishaja- vishaghna oushada prayoga \\
\hline Samanya Chikitsa & Sothagna and Mutrala \\
\hline Amajanya shotha & Shodhana \\
\hline In prvruddha dosha & Shirapradesh shotha-Shirovirechana nashya \\
\hline Shirapradesh shotha & Virechana \\
\hline Adhapradeshaja & Vamana \\
\hline Urdvapradeshaja & Rukshana \\
\hline Snehadhikajanya & Snehana \\
\hline Rukshadhikajanya & Niruhabasti \\
\hline Vibhanda in vatajashotha & \\
\hline
\end{tabular}

Ayurveda described the living body exists due to the microcirculation for the transportation of dosa \& asthayi dhatu and removal of the mala. The whole objectives of Ayurveda treatment are to maintain the equilibrium of dhatu. It can be explained in light of cellular homeostasis where cell membrane provides a boundary separating the internal workings of the cell from its external environment. Molecules can be transported across the cell membrane by passive transport or active processes. An active process (vata) is one that requires the expenditure of energy, while a passive process results solely from the inherent, random movement of molecules helps cells maintain homeostasis by keeping conditions within normal ranges inside all of an organism's cells [14]. Siranam ayama can be explained as Vascular dilation and hyperpermeability - the early events of inflammation - also enhance the transport of circulating immune cells to the tissue ${ }^{15}$.Kapha, Rakta \& Pitta enter the external as well as internal vessels and afflict the Vayu of that particular area resulting the blockage of micro- circulation. Meda Kaphanubandha (fat mixed with kapha) can block the channel also. This can clarify by the atherosclerotic process which is initiated by cholesterol-containing low-density lipoproteins (Sneha of pitta) accumulate in the intima layer and activate the endothelium. Leukocyte adhesion molecules and chemokines promote recruitment of monocytes and $\mathrm{T}$ cells. Monocytes differentiate into macrophages and upregulate pattern recognition receptors, including scavenger receptors and toll-like receptors. Scavenger receptors mediate lipoprotein internalization, which leads to foam-cell formation. Toll-like receptors transmit activating signals that lead to the release of cytokines, proteases, and vasoactive molecules. T cells in lesions recognize local antigens and mount T helper-1 responses with secretion of pro-inflammatory cytokines that contribute to local inflammation and growth of the plaque [16]. Endothelial dysfunction activate inflammation and it is among the first line of the body's defense system; it encounters and combats the perturbation of invading microbes and endogenous substances in response to tissue damage [17]. 
Vrana-Sopha can be developed to Vidradhi \& Arbuda. Chronic inflammation can induce certain cancers, and solid tumors, in turn, can initiate and perpetuate local inflammatory processes that foster tumor growth and dissemination. Consequently, inflammatory pathways have been targeted in attempts to control cancer [18]. (Fig no 3)

The validate the concept in terms of treatment then it was found that Dasamoola is the drug of choice in sotha. Dashamoola had anti-inflammatory, analgesic and anti-platelet effects comparable to that of aspirin [19]. Haritaki and Punnava are best drugs in Sopha. Terminalia chebula extracts have ability to inhibit inducible nitric oxide synthase (iNOS) and cyclooxygenase-2 (COX-2) in LPS-stimulated macrophages and Punarnavasava has antiinflammatory, central as well as peripheral antinociceptive, antipyretic and antiulcer activity [20], [21]. (Table no 6). All srotosothaka and Sothahara herbs have anticancer properties [22].

\section{CONCLUSION}

Sopha is linked with wide spectrum of Infectious as well as Non communicable disorders (NCD) as stated as chronic inflammation. This study also found out a range of therapies for sopha driven diseases. It can be recommended to include this concept of Sopha in Ayurveda undergraduate and post graduate curriculum.

\section{SOURCES OF FUNDING}

This research received no specific grant from any funding agency in the public, commercial, or not-for-profit sectors.

\section{CONFLICT OF INTEREST}

The author have declared that no competing interests exist.

\section{ACKNOWLEDGMENT}

None.

\section{REFERENCES}

[1] Signore A. About inflammation and infection. EJNMMI Res. 2013;3(1):8. Published 2013 Feb 1. doi:10.1186/2191-219X-3-8

[2] Kumar V, A. A., Fausto N. \& Aster J. C. in Robbins and Cotran Pathologic Basis of Disease 8th edn 43-77 (Saunders, 2009).

[3] Manabe, I. Chronic inflammation links cardiovascular, metabolic and renal diseases. Circ. J. 75, 2739-2748 (2011).

[4] Ward SG. New drug targets in inflammation: efforts to expand the anti-inflammatory armoury. Br J Pharmacol. 2008;153 Suppl 1(Suppl 1): S5-S6. doi: 10.1038/sj.bjp.0707628

[5] Aggarwal BB, Prasad S, Reuter S, et al. Identification of novel anti-inflammatory agents from Ayurvedic medicine for prevention of chronic diseases: "reverse pharmacology" and "bedside to bench" approach. Curr Drug Targets. 2011;12(11):1595-1653. doi:10.2174/138945011798109464

[6] Debnath T, Kim DH, Lim BO. Natural products as a source of anti-inflammatory agents associated with inflammatory bowel disease. Molecules. 2013;18(6):7253-7270. Published 2013 Jun 19. doi:10.3390/molecules18067253

[7] Sharma P V; Charaka Samhita Sutrasthana 18th Chapter (Tri Sothiya); 4th edn. Chaukhambha Sanskrit Sansthan Varanasi, India 1994.

[8] Charaka, Charaka Samhita of Agnivesa 'Vidyotini' hindi commentary by Kasinatha Sastri edited by Gangasahaya Pandey; Chikisa sthana 12th Chapter (Svayatu Chikisa) 4th edn. Chaukhambha Sanskrit Sansthan Varanasi, India 1994. p.403 
[9] Sushruta Samhita of Maharsi Sushruta edited with Ayurved Tattva Sandipaka by Kaviraj Ambika Duttta Shastri Part I 2008; Chikisa sthana 23th Chapter (Sopha Chikitsa) Chaukhambha Sanskrit prakashan Varanasi, Reprinted 2010

[10] Vagbhata. Astanga Hridaya (Sarvangsundara of Arundatta and Ayurveda Rasayan of Hemadri). Hari Sadashiva Shastri Paradakara, editor. 1 st ed. Varanasi: Chawkhambha Surbharti Prakashan; 2011. Nidhana sthana 13th Chapter (Pandu -Sopha Visarpa Nidana).

[11] Vagbhata. Astanga Hridaya (Sarvangsundara of Arundatta and Ayurveda Rasayan of Hemadri). Hari Sadashiva Shastri Paradakara, editor. 1 st ed. Varanasi: Chawkhambha Surbharti Prakashan; 2011. Chikisa sthana 17th Chapter (Sopha Chikitsa)

[12] Bhela Samhita by Bhela Charya. Translated by K.H. Krishnamurthy, Edited by Sharma P.V. Chowkhamba Vishwa Bharati, Varanasi;2000; Chikitsa sthana 17th Chapter (Svayatu Chikitsa)

[13] Upadhyaya Y. Madhav Nidana. Chaukhamba Prakashana: Varanasi; 2014. 36th Chapter (Sotha Nidana)

[14] Keener J., Sneyd J. (2009) Cellular Homeostasis. In: Keener J., Sneyd J. (eds) Mathematical Physiology. Interdisciplinary Applied Mathematics, vol 8/1. Springer, New York, NY

[15] Balkwill F, Mantovani A. Inflammation and cancer: back to Virchow? Lancet. 2001; 357:539-45. [PubMed: 11229684]

[16] Hansson GK. Inflammatory mechanisms in atherosclerosis. J Thromb Haemost. 2009 Jul; 7 Suppl 1:328-31.

[17] Yang X, Chang Y, Wei W. Endothelial Dysfunction and Inflammation: Immunity in Rheumatoid Arthritis. Mediators Inflamm. 2016; 2016:6813016. doi:10.1155/2016/6813016.

[18] Lance Munn, Cancer and Inflammation, Wiley Interdiscip Rev Syst Biol Med. 2017 March; 9(2):. doi:10.1002/wsbm.1370.

[19] Parekar RR, Bolegave SS, Marathe PA, Rege NN. Experimental evaluation of analgesic, anti-inflammatory and anti-platelet potential of Dashamoola. J Ayurveda Integr Med. 2015;6(1):11-18. doi:10.4103/09759476.146565

[20] A. Bag, S. Kumar Bhattacharyya, N. Kumar Pal, and R. R. Chattopadhyay, "Anti-inflammatory, anti-lipid peroxidative, antioxidant and membrane stabilizing activities of hydroalcoholic extract of Terminalia chebula fruits," Pharmaceutical Biology, vol. 51, no. 12, pp. 1515-1520, 2013.

[21] Gharate, M., Kasture, V. Evaluation of anti-inflammatory, analgesic, antipyretic and antiulcer activity of Punarnavasava: an Ayurvedic formulation of Boerhavia diffusa . Orient Pharm Exp Med 13, 121-126 (2013). https://doi.org/10.1007/s13596-012-0081-3

[22] Bharat agarwal, Priya Weesasinghe, Prachi garodia, Indra D.Bhat, From traditional Ayurvedic medicine to modern medicine: Identification of therapeutic target for suppression of Inflammation and cancer, Expert opinion on therapeutic target 2206,10(1),87-118 